\title{
PEMANFAATAN WASTAFEL PORTABLE SEMI-OTOMATIS DALAM UPAYA PENCEGAHAN PENYEBARAN COVID-19
}

\section{Utilization of Semi-automatic Portable Sink in Efforts to Prevent the Spread of Covid- 19}

\author{
Mustofa $^{1)}$, Evi Sunarti Antu' ${ }^{2}$, Sjahril Botutihe ${ }^{3)}$, Bayu S. Sinadia ${ }^{4}$ \\ 1,2,3,4 Program Studi Mesin dan Peralatan Pertanian, Politeknik Gorontalo \\ Email: mustofa@poligon.ac.id ${ }^{1)}$
}

\begin{abstract}
ABSTRAK
Propinsi Gorontalo merupakan propinsi terakhir terkonfirmasi positif Covid-19 dengan jumlah kasus sebanyak 126 tertanggal 5 Juni 2020. Pemerintah daerah melalui Gubernur, Walikota, dan Bupati telah bersama-sama berupaya dalam penanganan kasus Covid-19. Harapannya adalah tidak terjadi peningkatan kasus positif dan pasien yang dinyatakan positif agar segera ditangani dan sembuh. Program Studi Mesin dan Peralatan Pertanian Politeknik Gorontalo sebagai salah satu lembaga pendidikan yang tidak hanya bergerak di bidang pendidikan, melainkan juga bidang Tri Dharma Perguruan tinggi lainnya, termasuk Pengabdian kepada Masyarakat $(\mathrm{PkM})$ tentu harus memiliki andil dalam upaya penanganan kasus covid-19, khususnya di Propinsi Gorontalo. Melalui kegiatan PkM diharapkan dapat membantu pemerintah dalam penangan kasus Covid-19. Kegiatan PkM yang ditawarkan oleh Program Studi Mesin dan Peralatan Pertanian Politeknik Gorontalo adalah berupa perlatan cuci tangan portable semi otomatis yang dapat digunakan oleh masyarakat Kabupaten Bone Bolango dalam pencegahan penularan virus corona (Covid-19).
\end{abstract}

Kata kunci: virus corona, wastafel portable, semi-otomatis

\section{ABSTRACT}

Gorontalo Province is the last province to be confirmed positive for Covid-19 with a total of 126 cases dated June 5, 2020. The regional government through the Governor, Mayor and Regent have jointly made efforts in handling the Covid-19 case. The hope is that there will be no increase in positive cases and patients who test positive for immediate treatment and recovery. The Study Program of Agricultural Machinery and Equipment as an educational institution that is not only engaged in education, but also other Tri Dharma tertiary institutions, including Community Service (PkM) must certainly have a role in the efforts to handle the Covid-19 case, in particular. in Gorontalo Province. Through PkM activities, it is hoped that it can help the government in handling the Covid-19 case. The PkM activities offered by the Gorontalo Polytechnic Agricultural Machinery and Equipment Study Program are in the form of semi-automatic portable hand washing equipment that can be used by the people of Bone Bolango Regency in preventing the transmission of the corona virus (Covid-19).

Keywords: corona virus, portable sink, semi-automatic 


\section{PENDAHULUAN}

Saat ini seluruh dunia tengah dilanda suatu musibah yang dikenal dengan wabah menular akibat virus corona (Covid-19). Semakin hari terjadi peningkatan jumlah kasus yang dinyatakan positif terinveksi virus tersebut. Demikian juga terjadi peningkatan kasus meninggal dan sembuh. Hampir sebagian besar negara-negara terpapar kasus covid-19, tidak terkecuali Indonesia. Tertanggal 17 April 2020, di Indonesia terdapat sebanyak 5.923 kasus positif, kasus sembuh sebanyak 607, dan kasus meninggal sebanyak 520 (http://www.news.detik.com). Semua kasus positif tersebar di 34 propinsi di Indonesia, termasuk Propinsi Gorontalo.

Dengan semakin meningkatnya kasus positif covid-19, menuntut seluruh warga masyarakat mulai dari kalangan pejabat pemerintah (pusat maupun daerah), tokoh agama, tokoh masyarakat, tenaga medis, aparat kepolisian dan keamanan, masyarakat akademisi dan semua masyarakat di tingkat mengah ke bawah untuk bekerja sama dalam pencegahan dan penanganan kasus covid-19. Berbagai upaya telah dilakukan oleh pemerintah pusat maupun daerah melalui kebijakan pemberlakuan wilayah, social distancing, physical distancing, isolasi mandiri, karantina wilayah, menghimbau agar untuk sementara waktu masyarakat bekerja dari rumah (work from home), beribadah di rumah, termasuk kegiatan pembelajaran dilakukan secara daring (pembelajaran dalam jaringan). Kendati demikian, kasus masih terus meningkat hingga pemerintah melalui kementerian kesehatan mengeluarkan Peraturan Menteri Kesehatan RI No. 9 tahun 2020 tentang Pedoman Pembatasan Sosial Berskala Besar (PSBB). Upaya ini dilakukan tidak lain dalam rangka percepatan penangnan kasus covid-19.

Propinsi Gorontalo merupakan propinsi terakhir terkonfirmasi positif covid19 dengan jumlah kasus pertama kali pada tanggal 7 April 2020 sebanyak 4 kasus.
Dikutip Hingga saat ini kasus covid-19 di Gorontalo sebanyak 126 kasus (05 Juni 2020) dengan rincian jumlah sembuh sebanyak 43 kasus, 77 kasus yang dirawat, dan jumlah meninggal sebanyak 6 kasus (Gambar 1). Pemerintah daerah melalui Gubernur, Walikota, dan Bupati telah bersama-sama berupaya dalam penanganan kasus covid-19. Harapannya adalah tidak terjadi peningkatan kasus positif dan pasien yang dinyatakan positif agar segera ditangani dan sembuh. Program Studi Mesin dan Peralatan Pertanian Politeknik Gorontalo sebagai salah satu lembaga pendidikan yang tidak hanya bergerak di bidang pendidikan, melainkan juga bidang Tri Dharma Perguruan tinggi lainnya, termasuk Pengabdian kepada Masyarakat $(\mathrm{PkM})$ tentu harus memiliki andil dalam upaya penanganan kasus covid-19, khususnya di Propinsi Gorontalo.

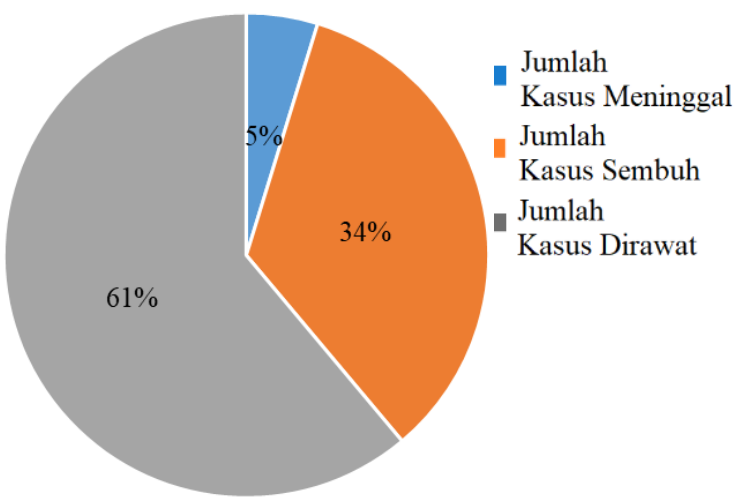

Gambar 1 Data kasus covid-19 di Gorontalo (https://humas.gorontaloprov.go.id/)

Melalui kegiatan PkM diharapkan dapat membantu pemerintah dalam penangan kasus covid-19. Kegiatan PkM yang ditawarkan oleh Program Studi Mesin dan Peralatan Pertanian Politeknik Gorontalo adalah berupa perlatan cuci tangan portable semi otomatis yang dapat digunakan oleh masyarakat dalam pencegahan penularan virus corona (covid19). Alat ini dapat digunakan khususnya di tempat-tempat yang masih potensial masyarakat melakukan aktivitasnya, seperti di rumah sakit, kantor pos, atau kantor layanan masyarakat lainnya, termasuk di 
pasar yang merupakan sumber bahan pokok untuk kebutuhan masyarakat.

\section{Permasalahan Mitra}

Hal-hal yang menjadi permasalahan diantaranya:

1. Beberapa tempat strategis belum menyediakan perlengkapan cuci tangan.

2. Perlengkapan cuci tangan yang disediakan hanya sebatas air dan sabun pencuci.

\section{SOLUSI DAN TARGET LUARAN}

\section{Solusi Permasalahan}

Beberapa hal yang dapat diupayakan sebagai solusi dari permasalahan di atas, diantaranya:

1. Membuat alat cuci tangan (wastafel) portable semi otomatis yang dilengkapi dengan:

a. Tong penampungan air

b. Tissu pembersih c. Sabun cuci tangan

d. Tong sampah tissue

e. Pembuka kran air dengan sistem injak kaki.

2. Menyediakan tempat-tempat umum dengan alat cuci tangan portable tersebut.

Secara ringkas, permasalahan dan solusi yang mendasari pelaksanaan kegiatan PkM ini disajikan pada Tabel 1.

Selain solusi di atas, beberapa hal yang menjadi rangkaian kegiatan Pengabdian kepada Masyarakat (PkM) adalah media sosialisasi pencegahan virus corona dengan mencantumkan langkahlangkah yang dapat dilakukan oleh masyarakat dalam pencegahan virus corona (covid-19) di spanduk/flyer.

\section{Luaran dan Target Capaian}

Adapun target luaran yang dicapai pada kegiatan PkM adalah seperti yang ada pada Tabel 1.

Tabel 1. Ringkasan permasalahan dan solusi

\begin{tabular}{clll}
\hline No & \multicolumn{1}{c}{ Permasalahan } & \multicolumn{1}{c}{ Solusi } & \multicolumn{1}{c}{ Luaran } \\
\hline 1 & $\begin{array}{l}\text { Alat cuci tangan yang } \\
\text { tersedia masih hanya } \\
\text { sebatas galon air dan } \\
\text { sabun cuci tangan }\end{array}$ & $\begin{array}{l}\text { Membuat alat cuci tangan } \\
\text { yang dilengkapi dengan tissu } \\
\text { tangan, tong sampah dan } \\
\text { sistem pembuka kran \& tong } \\
\text { sampah yang semi otomatis. } \\
\text { Meberapa tempat- }\end{array}$ & $\begin{array}{l}\text { Alat Cuci Tangan Semi- } \\
\text { otomatis }\end{array}$ \\
& $\begin{array}{l}\text { Menyediakan alat cuci tangan } \\
\text { tempat umum belum } \\
\text { portable semi otomatis } \\
\text { tersedia alat cuci }\end{array}$ & $\begin{array}{l}\text { Tersedianya alat cuci tangan } \\
\text { di tempat-tempat umum } \\
\text { (kantor desa) }\end{array}$ \\
$\begin{array}{l}\text { Keterbatasan bahan } \\
\text { baku pembuatan alat } \\
\text { cuci tangan portrable } \\
\text { semi otomatis }\end{array}$ & $\begin{array}{l}\text { Bekerjasama dengan } \\
\text { pemerintah daerah untuk } \\
\text { menyediakan bahan-bahan } \\
\text { yang digunakan dalam } \\
\text { pembuatan alat tersebut untuk } \\
\text { skala besar }\end{array}$ & $\begin{array}{l}\text { Alat cuci tangan semi } \\
\text { otomatis dalam jumlah yang } \\
\text { banyak }\end{array}$ \\
& & & \\
\hline
\end{tabular}

\section{METODE PELAKSANAAN}

\section{Fokus dan Sasaran Kegiatan}

Kegiatan Pengabdian kepada Masyarakat (PkM) dalam hal ini difokuskan pada upaya dan keikut sertaan Perguruan Tinggi dalam pengananan kasus covid-19.
Oleh karena itu, pelaksanaannya tidak dalam bentuk penyuluhan dan sosialisasi yang dapat menyebabkan berkumpulnya banyak orang, dimana kegiatan seperti ini salah satu diantara upaya pemerintah untuk memutus mata rantai penyebaran virus covid-19. Kegiatan PkM ini ditekankan pada 
pemanfaatan suatu alat cuci tangan portable yang dapat digunakan di tempat-tempat layanan masyarakat yang masih potensial melakukan aktivitasnya sehari-sehari seperti rumah sakit, puskesmas, kantor pos, kantor layanan masyarakat lainnya, dan termasuk tempat sumber penyedia kebutuhan pokok masyarakat seperti supermarket, minimarket, pasar tradisional dan warungwarung sembako lainnya.

\section{Skema dan Diagram Alir Kegiatan}

Skema pelaksanaan kegiatan Pengabdian kepada Masyarakat disajikan dalam diagram alir pada Gambar 2. Skema kegiatan PkM pemanfaatan wastafel semiotomatis sebagai upaya pencegahan penularan Covid-19 secara terperinci diuraikan sebagai berikut:

1. Survei Kondisi

Kegiatan ini dilakukan untuk mengetahui kondisi tempat-tempat yang potensial dan cocok untuk uji coba penerapan alat.

2. Pembuatan Alat

Pembuatan alat dilakukan oleh Tim PkM Program Studi Mesin dan Peralatan Pertanian di Laboratorium Mesin Politeknik Gorontalo.

3. Uji Coba Alat

Sebelum diterapkan di masyarakat, alat dilakukan uji coba untuk mengetahui utilitas dan tujuan penerapannya.

4. Sosialisasi Penerapan Alat

Sosialisasi yang dimaksud adalah sosialisasi terbatas ke salah satu kantor layanan masyarakat semisal Kantor Polsek/Polres/Puskesmas sebagai pengguna alat nantinya. Kegiatan ini dilakukan dengan memberikan pemahaman dan penjelasan terkait cara kerja dan tata cara penggunaan alat.

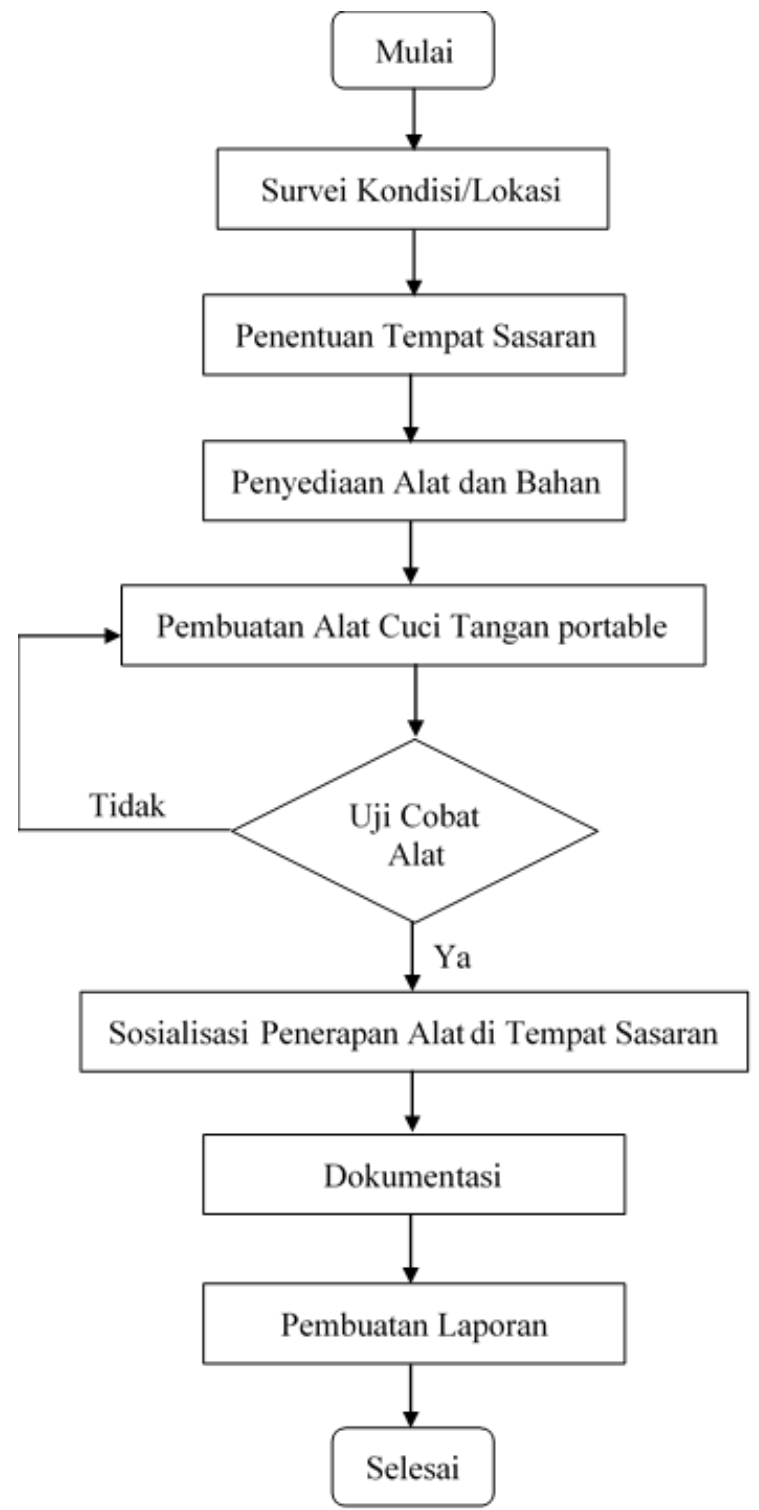

Gambar 2. Diagram alir kegiatan PkM

5. Pembuatan Laporan

Laporan yang dimaksud adalah laporan hasil penerapan alat terkait manfaat dan uji kegunaannya di salah satu kantor layanan masyarakat.

\section{HASIL DAN PEMBAHASAN}

\section{Survei Lokasi}

Survei lokasi merupakan kegiatan awal yang dilakukan untuk menentukan tujuan/sasaran kegiatan pengabdian kepada masyarakat. Konsep dasar dalam penentuan sasaran kegiatan bahwa tempat tersebut merupakan tempat layanan masyarakat yang masih tetap melakukan kegiatan aktivitas 
dan rutinitasnya. Hal ini mengingat dengan adanya aturan dan regulasi dari pemerintah terkait penanganan dan pencegahan virus corona (covid-19) banyak tempat-tempat yang tidak melakukan aktivitas/tidak beroperasi. Berdasarkan konsep dasar itulah, tim PkM menentukan bahwa sasaran kegiatan adalah kantor desa sebagai pusat layanan masyarakat, dalam hal ini Kantor Desa Bubeya Kecamatan Suwawa, Kab. Bone Bolango.

Selain konsep dasar di atas, ada beberapa hal yang menjadi indikator suatu tempat layak dijadikan lokasi kegiatan PkM, terutama di masa pandemi covid-19. Indikator tersebut adalah bahwa di desa tersebut akan ada layanan masyarakat berkaitan dengan BLT dari pemerintah. Sehingga dengan kondisi seperti ini mengharuskan pihak desa menerapkan protokol kesehatan yang ditetapkan. Salah satunya adalah dengan menyediakan alat cuci tangan yang dapat dimanfaatkan oleh masyarakat selama kegiatan pelayanan. Aspek lain yang mendukung dijadikannya Desa Bubeya sebagai tempat sasaran kegiatan PkM adalah belum tersedianya tempat cuci tangan yang memadai. Artinya, tempat cuci tang yang disediakan masih terbatas dan sederhana.

\section{Pembuatan Alat}

Pembuatatan alat cuci tangan (wastafel) portable dilaksanakan di Laboratorium Mesin Umum Program Studi Mesin dan Peralatan Pertanian. Alat yang dibuat merupakan wastafel portable semi otomatis yang dilengkapi dengan beberapa komponen (Gambar 3). Portable yang dimaksud dapat dipindahkan dan dibawa ke tempat yang berbeda-beda.

Komponen-komponen

tersebut diantaranya tempat sampah, tissue, sabun cuci tangan, kran air sistem injak, inlet dan outlet saluran air.

a) Tempat sampah. Tempat cuci tangan pada umumnya memiliki tempat sampah yang terpisah. Tempat sampah ini dapat dibuka dan dipasang lagi ke dalam rangkaian alat cuci tangan (wastafel) portable ini sehingga memudahkan kita untuk membuang sampah jika telah penuh.

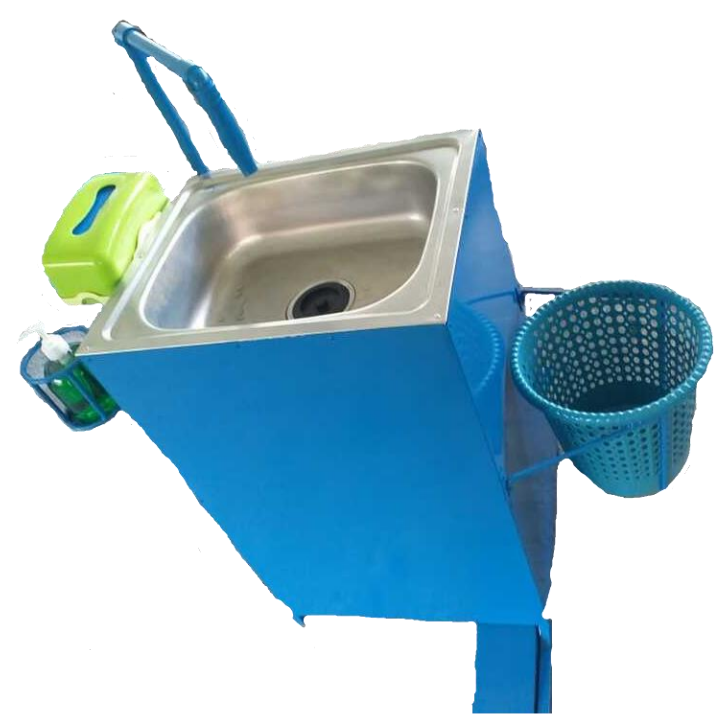

Gambar 3. Wastafel portable

b) Sebagaimana tempat sampah, tempat dan tissue umumnya juga terpisah sehingga ketika dipindah harus membutuhkan tempat khusus. Pemilihan tissue sebagai pengering tangan setelah cuci tangan adalah karena tissue sekali pakai sehingga kemungkinan kecil terjadi penularan virus, berebda halnya dengan kain lap yang umumnya digantung di samping wastafel di rumahrumah makan dan sejenisnya.

c) Tempat sabun cuci tangan. Komponen ini juga tergabung dalam rangka alat cuci tangan.

d) Saluran inlet dan outlet. Saluran inlet merupakan saluran dimana air bersih dari penampungan/PDAM masuk ke dalam penampung alat. Sedangkan saluran outlet adalah sisa air setelah cuci tangan.

e) Pedal pembuka kran. Komponen ini dimaksudkan untuk membuka kran air dari saluran inlet ke kran. Artinya, air kran tidak akan keluar kecuali harus dilakukan serangkaian kerja dengan menginjak pedal. Alasan utama 
menggunakan sistem injak adalah untuk menghindari kontak langsung dengan tangan dimana penggunaan ini memungkinkan banyak kontak antara orang satu dengan yang lainnnya, sehingga ada kemungkinan terjadi penyebaran virus melalui kontak tangan.

Wastafel portable yang dibuat menerapkan sistem injak sebagai salah satu metode untuk membuka kran. Hal ini tidak menggunakan sistem kran pada umumnya yang mana air akan mengalir ketika katup (valve) kran dibuka dengan tangan. Penggunaan tangan dalam membuka kran air memungkinkan menjadi media penyebaran virus, dimana setiap orang yang menggunakan alat tentunya kontak langsung dengan kran. Oleh karena itu, sistem injak dalam mengalirkan air menjadi alternatif untuk mencegah penyebaran virus corona (covid-19) melalui kontak tangan.

Cara kerja alat cuci tangan (wastafel) portable adalah sebagai berikut:

a) Sambungkan pipa di bagian belakang dengan saluran air mengalir.

b) Injak pedal maka air akan keluar dari kran pada bagian atas wastafel.

c) Air siap digunakan untuk mencuci tangan.

d) Untuk menghentikan air, lepaskan kaki dari pedal.

e) Air sisa akan mengalir melalui saluran bahwa wastafel.

\section{Kordinasi dan Persiapan}

Koordinasi dilakukan dengan maksud untuk mengetahui sejauh mana kesiapan tempat sasaran sebelum pelaksanaan kegiatan PkM. Koordinasi diawali dengan pemberitahuan secara resmi dari pihak penyelenggara, dalam hal ini kampus. Pemberitahuan dimaksudkan untuk menyampaikan informasi bahwasannya akan dilaksanakan kegiatan sosialisasi penerapan alat cuci tangan portable pada waktu yang ditentukan.

Berdasarkan hasil koordinasi, pihak aparat Desa Bubeya, terutama kepala desa sangat antusias dan mendukung adanya kegiatan tersebut. Hal ini dibuktikan dengan terlaksananya kegiatan satu hari setelah adanya koordinasi.

Persiapan yang dimaksud adalah mempersiapkan segala kebutuhan yang akan digunakan selama kegiatan PkM. Beberapa hal yang dipersiapkan adalah transportasi ke lokasi sasaran, dokumen administrasi, spanduk, alat cuci tangan, dan komponen pendukung lainnya. Termasuk dalam tahapan ini adalah menyiapkan tenaga teknis untuk melakukan assembly dan pemasangan alat cuci tangan di lapangan, serta beberapa peralatan yang diperlukan.

\section{Sosialisasi}

Tahapan akhir dari kegiatan Pengabdian kepada Masyarakat (PkM) adalah sosialisasi. Kegiatan ini dilakukan melalui beberapa tahapan berikut:

1. Serah terima alat antara tim PkM kepada aparat desa. Penyerahan alat oleh tim PkM kepada Desa Bubeya secara langsung diterima oleh Kepala Desa Bubeya (Gambar 4).

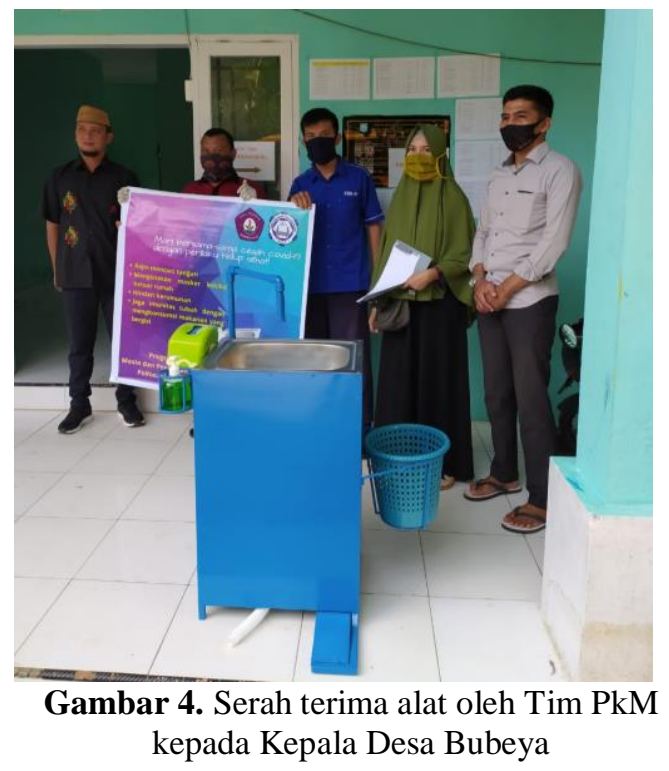

2. Sosialisasi dan penjelasan singkat terkait cara kerja alat (Gambar 5). Kegiatan ini disampaikan oleh salah satu tim PkM kepada Kepala Desa Bubeya dan beberapa perangkatnya. Penjelasan ini 
dimaksudkan untuk memberikan pengetahuan kepada aparat desa terkait penggunaan alat sehingga alat dapat dimanfaatkan sebagaimana fungsinya menurut langkah-langkah yang telah ditentukan.

3. Uji coba dilakukan oleh salah satu teknisi Laboratorium Mesin Umum Program Studi Mesin dan Peralatan Pertanian yang termasuk salah satu tim PkM (Gambar 6). Uji coba ini dimaksudkan untuk mengetahui apakah alat benar-benar berfungsi. Disamping itu, untuk memberikan penjelasan secara teknis mekanisme penggunaan alat sehingga lebih jelas dan mudah dipahami.

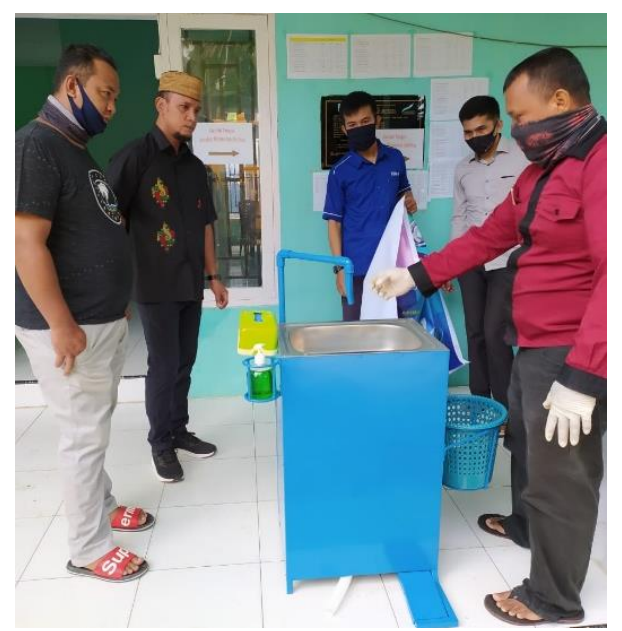

Gambar 5. Penjelasan cara kerja Alat

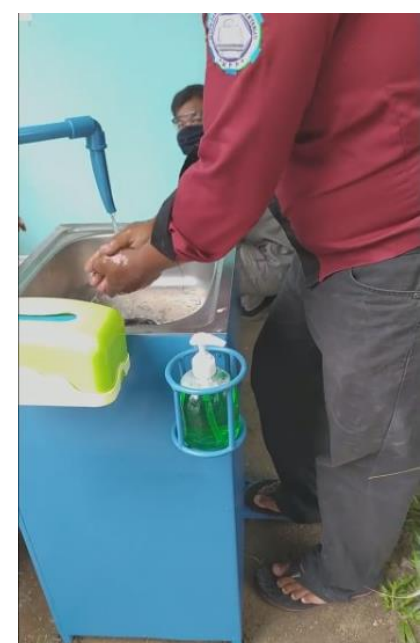

Gambar 6. Uji Coba Wastafel di Depan Kantor Desa
Berdasarkan kegiatan di atas, diketahui bahwa pihak desa sangat bersyukur dengan adanya alat tersebut. Mengingat kantor desa merupakan salah satu tempat layanan masyarakat yang harus tetap beroperasi meskipun masa pandemi covid-19. Hal ini karena berbagai kegiatan dan kebutuhan masyarakat terkadang berkaitan dengan hal-hal yang melibatkan kantor desa. Salah satunya adalah dengan adanya program pemerintah yang terkait dengan BLT (bantuan langsung tunai). Pemberian BLT didasarkan pada Peraturan Menteri Desa, Pembangunan Daerah Tertinggal, dan Transmigrasi RI No. 6 tahun 2020, dimana pihak-pihak yang berhak mendapatkan BLT adalah mereka yang tergolong keluarga miskin. Keluarga miskin yang dimaksud adalah keluarga yang kehilangan mata pencaharian atau pekerjaan, belum terdata menerima Program Keluarga Harapan (PKH), Bantuan Pangan Non Tunai (BPNT), dan kartu pra kerja, serta yang mempunyai anggota keluarga yang rentan sakit menahun/kronis.

Desa sebagai salah satu tempat layanan masyarakat bertanggung jawab dalam menyalurkan BLT menurut peraturan perundang-undangan yang berlaku. Hal ini sebagaiman dikemukakan oleh Dirjen Pengimbangan Keuangan RI dalam FAQ terkait Kebijakan Dana Desa dalam rangka penangan Covid-19, bahwa Kepala Desa dan aparat desa menyalurkan BLT Desa kepada masyarakat miskin dan tentunya dalam pengawasan dibantu oleh pemerintah daerah setempat. Dengan adanya kebijakan ini, menuntut Kepala Desa dalam melayani masyarakat, khususnya yang berkaitan dengan BLT Desa harus memperhatikan protokol kesehatan dan kebijakan lainnya terkait penanganan covid-19. Salah satu upayanya adalah harus menyediakan tempat cuci tangan di setiap tempat layanan masyarakat. Oleh karena itu, Program Studi Mesin dan Peralatan Pertanian (MPP) Politeknik Gorontalo sebagai salah satu perguruan tinggi di wilayah Kabupaten Bone Bolango memiliki andil dalam upaya 
penanganan dan pencegahan covid-19. Upaya ini merupakan salah satu bentuk tri dharma perguruan tinggi, yakni pengabdian kepada masyarakat $(\mathrm{PkM})$. Kegiatan PkM ini tentunya harus berkesesuaian dengan apa yang diinginkan oleh mitra, dalam hal ini Kantor Desa Bubeya.

Peran Prodi MPP Politeknik Gorontalo dalam hal kegiatan PkM adalah menyediakan alat cuci tangan yang dapat digunakan oleh aparat desa dan masyarakat. Alat ini sebagaimana dijelaskan pada uraian sebelumnya menerapkan sistem injak untuk mengalirkan air kran. Hal ini dimaksudkan untuk menghindari kemungkinan kontak tangan langsung dengan kran yang memungkinkan menjadi penyebab penyebaran virus corona (covid-19). Dengan adanya alat ini diharapkan dapat membantu masyarakat dalam penangan covid-19 dan tentunya demi kemanfaatan masyarakat secara umum.

\section{KESIMPULAN DAN SARAN}

\section{Kesimpulan}

Perguruan tinggi sebagai salah satu lembaga pendidikan memiliki peran yang sangat penting terutama dalam masalahmasalah kekinian (terbaru). Dalam kaitannya dengan kondisi masa pandemi covid-19, solusi dan upaya penanganan sangat diperlukan terutama bagi daerahdaerah yang terdampak. Upaya dan peran Prodi Mesin dan Peralatan Pertanian Politeknik Gorontalo dengan menyediakan alat cuci tangan (wastafel) portable menjadi solusi yang sangat membantu khususnya bagi masyarakat Desa Bubeya Kec. Suwawa, Kab. Bone Bolango. Upaya tersebut dilakukan sebagai langkah nyata dalam penanganan dan pencegahan covid19 di Provinsi Gorontalo, khususnya di Kec. Suwawa, Kab. Bone Bolango.

\section{Saran}

Adanya kerja sama yang saling bersinergi antara pemerintah daerah dan peguruan tinggi terutama dalam menyelesaikan permasalahan terkini dan terbaru. Pemerintah daerah bersama-sama perguruan tinggi dapat membuat alat cuci tangan (wastafel) portable secara massal sehingga dapat dimanfaatkan oleh masyarakat luas, khususnya di tempattempat yang masih potensial dikunjungi masyarakat seperti kantor desa, kantor pos, kantor polisi, puskesmas dan rumah sakit serta kantor layanan masyarakat lainnya.

\section{DAFTAR PUSTAKA}

Dirjen Perimbangan Keuangan RI, 2020, FAQ terkait Kebijakan Dana Desa dalam Rangak Penanganan Covid-19 http://www.djpk.kemenkeu.go.id/wpcontent/uploads/2020/04/FAQ-DanaDesa-COVID-19.pdf diakses pada tanggal 07 Juni 2020.

Salinan Peraturan Menteri Desa, Pembangunan Daerah Tertinggal, dan Transmigrasi Republik Indonesia Nomor 6 Tahun 2020 tentang Perubahan atas Peraturan Menteri Desa, Pembangunan Daerah Tertinggal, dan Transmigrasi Nomor 11 Tahun 2019 tentang Prioritas Penggunaan Dana Desa Tahun 2020 https://kemenkeu.go.id/media/15111/pe rmendesa-nomor-6-tahun-2020-

pdfpdf.pdf diakses pada tanggal 07 Juni 2020.

https://news.detik.com/berita/d4981052/data-corona-terkait-indonesia17-april-2020-pukul-1700-wib diakses pada tanggal 18 April 2020.

https://humas.gorontaloprov.go.id/updatecovid-19-gorontalo-14-orang-sembuhlima-pasien-baru/ diakses pada tanggal 06 Juni 2020. 